\title{
MACROALGAE DIVERSITY AND LIFE FORMS OF INTER-TIDAL ROCKY SHORES
}

\author{
Muta Harah Zakaria ${ }^{{ }^{*}}$, Wong Siaw Chia ${ }^{1}$, Japar Sidik Bujang ${ }^{1}$, Aziz Arshad $^{2}$ and Hisao Ogawa $^{3}$ \\ 'Faculty of Agriculture and Food Sciences, Universiti Putra Malaysia Bintulu Campus, \\ Nyabau Rd., P.O. Box 396, 97008 Bintulu, Sarawak, Malaysia \\ *e-mail:drmuta@btu.upm.edu.my \\ ${ }^{2}$ Faculty of Science, Universiti Putra Malaysia, 43400 UPM Serdang, Selangor Darul Ehsan, Malaysia \\ ${ }^{3}$ Faculty of Fisheries, Kitasato University, Sanriku-cho, Ohofunato City, Iwate 022-0101, Japan
}

\begin{abstract}
A study on macroalgae diversity and life form was carried out at inter-tidal rocky shores of Similajau National Park, Bintulu, Sarawak. Thirty five species were identified in this study, of which 15 belong to the division Rhodophyta, 12 to the Chlorophyta and 8 to Phaeophyta. Fifteen species are new records to the Park. Irrespective of areas, macroalgae from the three divisions; Chlorophyta, Phaeophyta and Rhodophyta did not show any distinct zonation. There was high number of macroalgae species in rocky area related to the sandy area. The high representation of macroalgae from rocky area reflects the availability of stable substrate and microhabitats for the occurrence and diversity of macroalgae species. The sandy area lacks hard structure responsible for the relatively low diversity of macroalgae. Four types of macroalgae life forms were identified namely epilithic, epipelic, epizoic and epiphytic. The general distribution, occurrence and a list of the macroalgae is presented.
\end{abstract}

Keywords: diversity, distribution, percent cover, percent frequency, life forms

\section{INTRODUCTION}

Similajau National Park lies just north of Bintulu, home to Malaysia's thriving liquid natural gas export industry. Similajau was gazetted on $1^{\text {st }}$ December 1976 to conserve the flora, fauna and unique geological formations along the extensive coastal foreshore. The vegetation consists of three main types namely; Beach, Kerangas and Mixed Dipterocarp Forest, home to various species of plants, trees and wildlife. Among the well-known plants found here are the Tongkat Ali (Eurycoma longifolia) and Bintangor trees (Barringtonia asiatica). The terrestrial fauna of the park comprises 24 species of mammals, such as gibbons, banded langurs and long-tailed macaque. The Park records the presence of 185 species of birds, which include hornbills and migratory waterbirds like storms stork (http://www.sarawakforestry.com). Along parts of the coastline, sandstone cliffs and rocky shores line the foreshore. The rocky shores are the least explored as they are submerge under waters and only periodically exposed at low spring tides. Macroalgae dominated the rocky shores habitats. Studies on them are scare and published records of marine macroalgae are those from Fisheries Research Centre of Sarawak (http:// www.fri.gov.my/friswak/eseaweed.htm) and Muta Harah et al., (2006). The present study of macroalgal resources was conducted along the rocky shores from Tg. Batu Kudu to Tg. Lubok Padok. This study examined the diversity with respect to the general distribution pattern, occurrences and life forms of macroalgae associated with rocky shores.

\section{MATERIALS AND METHODS}

The stretch of Tg. Batu Kudu -Tg. Lubok Padok of the Similajau National Park is located at Latitude $3^{\circ} 21^{\prime} 13.6^{\prime \prime} \mathrm{N}$, Longitude $113^{\circ} 09^{\prime} 21.4^{\prime \prime}$ E. Macroalgae from rocky and rocky-sandy areas were sampled following the procedure of Saito and Atobe (1970) and collected during low tide between August and September 2006. The sites were selected based on the substrata; the sites with diverse microhabitats as rocky inter-tidal zones with depressions and tide pools and, sandy 
areas. Three line transects were laid for each of the rocky and rocky-sandy areas. A quadrat of 50 $\mathrm{cm} \times 50 \mathrm{~cm}$ with 25 sub-divisions $(10 \mathrm{~cm} \times 10 \mathrm{~cm})$ was placed at $5 \mathrm{~m}$ interval along each transect. Macroalgae species degree of cover and the corresponding indices (refer to Table 1) in each of the 25 sub-divisions were recorded. Parameters obtained from each quadrat were: (a) Frequency $(\%), \mathrm{F}=\mathrm{qn} / 25 \times 100=\mathrm{qn} / 4$; where $\mathrm{qn}$ is the number of sub-divisions (within the quadrat in which an algae species occurred; (b) Cover (\%) or $\mathrm{C}$ is used to compute for the area in the substrate occupied by the species. For convenience, the index numbers: 5, 4, 3, 2, 1 are used for recording data in the field as shown in Table 1. $\mathrm{C}$ is given in percentage $(\%)=\left(\mathrm{qn}_{5} \times \mathrm{c}_{5}\right)+\left(\mathrm{qn}_{4} \times \mathrm{c}_{4}\right)+\left(\mathrm{qn}_{3} \times\right.$ $\left.\mathrm{c}_{3}\right)+\left(\mathrm{qn}_{2} \times \mathrm{c}_{2}\right)+\left(\mathrm{qn}_{1} \times \mathrm{c}_{1}\right)=\left(\mathrm{qn}_{5} \times 3\right)+\left(\mathrm{qn}_{4} \mathrm{x}\right.$ $1.5)+\left(\mathrm{qn}_{3} \times 0.75\right)+\left(\mathrm{qn}_{2} \times 0.375\right)+\left(\mathrm{qn}_{1} \times 0.1875\right)$; where $\mathrm{qn}_{\mathrm{n}}$ is the number of sub-divisions in which a species appeared to have the corresponding coverage area described in the above table and (c) dominance is used to determine which macroalgae species dominates in an area. Thus, fraction contributed by each species to the total algae cover is computed. Fraction contributed by each species to total algae cover $=\%$ cover of individual species / total $\%$ of all seaweed species. Dominant species are those species whose cover values constitute $50 \%$ or more fraction of the total algae cover while sub-dominant species are whose cover values when added to those of the dominant species, equals $75 \%$ or more of the total algae cover.

\section{RESULTS AND DISCUSSION}

\section{Floristic and diversity}

General observations indicated that macroalgae were only found from $15 \mathrm{~m}$ to $75 \mathrm{~m}$ of the shoreline to the sea. Profiles of macroalgae distributional pattern from the highest tide mark towards the sea for both rocky and rocky-sandy areas are presented in Figures 1 and 2. All three major divisions; Chlorophyta, Phaeophyta and Rhodophyta of macroalgae were recorded at the study sites (Table 2) and their species are overlapped with no distinct zonation. A few assumptions could be the cause for the distributional trend; (i) some macroalgae might lose their attachment from the ordinary substrate and were swept down away as drift macroalgae (Khew, 1978), (ii) macroalgae could be swept to other areas and may still live (Chapman, 1979), (iii) some of the macroalgae might change their morphology with some modification depending on their required environment (Norton et al., 1981).

Thirty five species were identified in this study, of which 15 belong to the division Rhodophyta, 12 to the Chlorophyta and 8 to Phaeophyta. Comparing to the records of macroalgae collection for Similajau National Park by Fisheries Research Centre Sarawak (2000), this present study observed 15 species are new records for Similajau National Park (Table 2). In terms of percent frequency and percent cover the dominant macroalgae belong to the Rhodophyta (Fig. 3a) which require hard substrate for attachment and Chlorophyta (Fig. 3b) where members have special attachment structures that can be used for attachment to rocks. Several macroalgae are dominant than others in terms of species percentage contribution (Figs. 4a and 4b). Macroalgae species distribution pattern is related to the stability of substrate and the type for attachment of macroalgae thallus (McConnaughey, 1978; Pole, 1974; Teo and Wee, 1983).

There was a high number of macroalgae species in rocky area relative to rocky-sandy area (Table 2). The rocky area comprised by broad inter-tidal zone, a great variety of microhabitats with stable substrate, including pebbles, depressions and tide pools (Fig. 1). In rocky area where there are tide pools with sand as bottom substrate, Avrainvillea obscura thrives as it possess pseudobulbous holdfast which enable it to affix to soft substrate such as sand. In addition

Table 1. Indices of the degree of macroalgae cover and its representative multiplier

\begin{tabular}{|c|l|l|}
\hline Indices & \multicolumn{1}{|c|}{ Degree of algae cover } & \multicolumn{1}{c|}{ Multiplier, $\boldsymbol{c}_{\boldsymbol{n}}$} \\
\hline 5 & Covering $1 / 2-1 / 1$ of substratum surface & 3.0 \\
\hline 4 & Covering $1 / 4-1 / 2$ of substratum surface & 1.5 \\
\hline 3 & Covering $1 / 8-1 / 4$ of substratum surface & 0.75 \\
\hline 2 & Covering $1 / 16-1 / 8$ of substratum surface & 0.375 \\
\hline 1 & Covering less than $1 / 16$ of substratum surface & 0.1875 \\
\hline
\end{tabular}



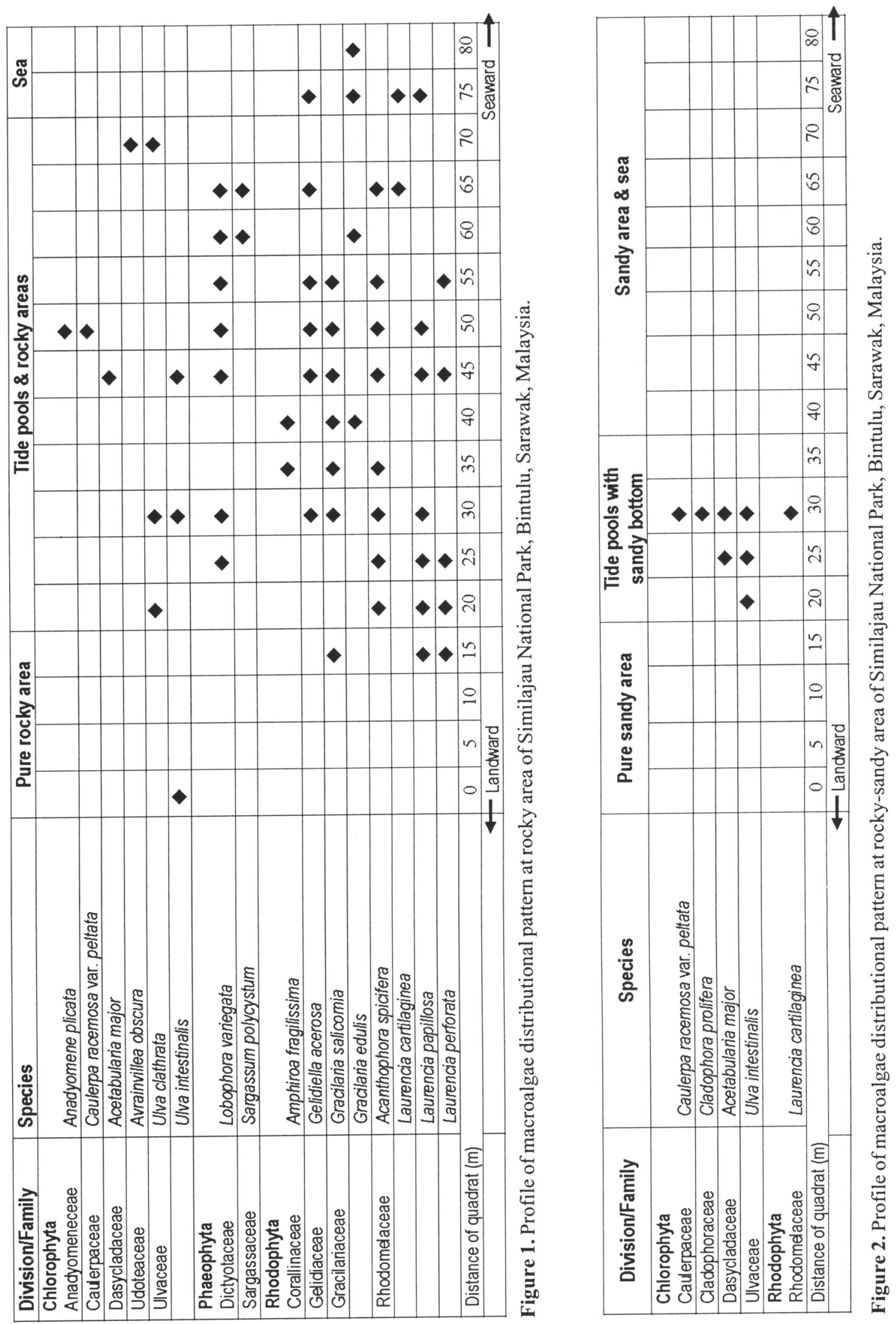
Table 2. Macroalgae species of Tg. Batu Kudu -Tg. Lubok Padok of the Similajau National Park, Bintulu, Sarawak

\begin{tabular}{|c|c|c|c|c|c|c|}
\hline \multirow[b]{2}{*}{ No. } & \multirow[b]{2}{*}{ Division/Family } & \multirow[b]{2}{*}{ Species } & \multicolumn{2}{|c|}{ SNP } & \multirow[b]{2}{*}{ Substrate } & \multirow[b]{2}{*}{ Life Form } \\
\hline & & & Rocky & $\begin{array}{l}\text { Rocky- } \\
\text { Sandy }\end{array}$ & & \\
\hline 1. & $\begin{array}{l}\text { Chlorophyta } \\
\text { Anadyomeneceae }\end{array}$ & Anadyomene plicata C. Agardh & + & & Rocks & Epl \\
\hline 2. & Caulerpaceae & $\begin{array}{l}\text { Caulerpa racemosa var. peltata } \\
\text { (Lamouroux) Eubank }\end{array}$ & + & + & Mud, sand, rocks & Epi/Epl \\
\hline NR3. & & Caulerpa taxifolia (Vahl) C. Agardh* & & + & Sand & Epi \\
\hline NR4. & Cladophoraceae & $\begin{array}{l}\text { Chaetomorpha crassa (C. Agardh) } \\
\text { Kutzing }^{*}\end{array}$ & + & & Sand & Epi \\
\hline 5. & & $\begin{array}{l}\text { Chaetomorpha minima Collins \& } \\
\text { Harvey* }^{*}\end{array}$ & + & & Seaweed & Epp \\
\hline NR6. & & Cladophora prolifera (Roth) Kutzing & + & + & Mud, sand, rocks & Epi/Epl \\
\hline 7. & Dasycladaceae & Acetabularia major G. Martens & + & + & Rocks, sand & Ep//Epi \\
\hline NR8. & Siphonocladaceae & $\begin{array}{l}\text { Struvea anastomosans (Harvey) } \\
\text { Piccone \& Grunow ex Piccone }{ }^{\star}\end{array}$ & + & 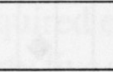 & Rocks, seaweed & Ep//Epp \\
\hline NR9. & Udoteaceae & $\begin{array}{l}\text { Avrainvillea obscura (C. Agardh) J. } \\
\text { Agardh }\end{array}$ & + & & Mud, sand, rocks & Epi/Epl \\
\hline NR10. & Ulvaceae & Ulva clathrata (Roth) Greville & + & + & $\begin{array}{l}\text { Mud, sand, rocks, } \\
\text { barnacles }\end{array}$ & Epi/Ep/Ez \\
\hline 11. & & Ulva intestinalis (Linnaeus) Nees & + & + & Sand, mud, rocks & Epi/Epl \\
\hline 12. & Valoniaceae & Valonia aegagropila C. Agardh* & + & & Rocks & Epl \\
\hline 13. & $\begin{array}{l}\text { Phaeophyta } \\
\text { Dictyotaceae }\end{array}$ & Dictyopteris delicatula Lamouroux* & + & & Sand, rocks & Epi/Epl \\
\hline NR14. & & Dictyota cervicornis Kutzing ${ }^{*}$ & + & 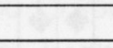 & Sand, rocks & Epi/Epl \\
\hline 15. & & $\begin{array}{l}\text { Dictyota dichotoma (Hudson) } \\
\text { Lamouroux* }\end{array}$ & + & & Sand, rocks & Epi/Epl \\
\hline 16. & & $\begin{array}{l}\text { Lobophora variegata (Lamouroux) } \\
\text { Wolmsley }\end{array}$ & + & + & $\begin{array}{l}\text { Barnacles, rocks, } \\
\text { mud }\end{array}$ & Ez/Epl \\
\hline 17. & & Padina australis Hauck* & + & & Rocks & Epl \\
\hline NR18. & & Padina minor Yamada* & + & & Rocks & Epl \\
\hline NR19. & Sargassaceae & $\begin{array}{l}\text { Sargassum fusiformis (Harvey) } \\
\text { Setchell }^{*}\end{array}$ & + & & Sand & Epi \\
\hline NR20. & & Sargassum polycystum C. Agardh & + & + & $\begin{array}{l}\text { Mud, rocks, snails, } \\
\text { barnacles }\end{array}$ & Epi/Epl/Ez \\
\hline 21. & & Sargassum sp. ${ }^{\star}$ & + & & Rocks & Epl \\
\hline NR22. & $\begin{array}{l}\text { Rhodophyta } \\
\text { Ceramiaceae }\end{array}$ & $\begin{array}{l}\text { Ceramium flaccidum (Harvey ex } \\
\text { Kutzing) Ardissone* }\end{array}$ & + & & Seaweed & Epp \\
\hline 23. & & $\begin{array}{l}\text { Ceramium gracillimum } \\
\text { (Kutzing)Zanardini }^{*}\end{array}$ & + & & Seaweed & Epp \\
\hline NR24. & Champiaceae & Champia parvula (C. Agardh) Harvey* & + & & Seaweed & Epp \\
\hline 25. & Corallinaceae & $\begin{array}{l}\text { Amphiroa fragilissima (Linnaeus) } \\
\text { Lamouroux }\end{array}$ & + & & Mud, sand, rocks & Epi/Epl \\
\hline NR26. & & $\begin{array}{l}\text { Cheilosporum acutilobum (Decaisne) } \\
\text { Piccone }^{\star}\end{array}$ & + & & Rocks & Epl \\
\hline NR27. & & Sporolithon sp." & + & & Rocks & Epl \\
\hline 28. & Galaxauraceae & $\begin{array}{l}\text { Galaxaura oblongata (Ellis \& Solander) } \\
\text { Lamouroux* }\end{array}$ & & + & Sand, rocks & Epi/Epl \\
\hline 29. & Gelidiaceae & $\begin{array}{l}\text { Gelidiella acerosa (Forsskal) Feldmann } \\
\text { \& Hamel }\end{array}$ & + & & $\begin{array}{l}\text { Mud, sand, rocks, } \\
\text { barnacles }\end{array}$ & Epi/Epl/Ez \\
\hline 30. & Gracilariaceae & $\begin{array}{l}\text { Gracilaria salicornia (C. Agardh) } \\
\text { Dawson }\end{array}$ & + & + & $\begin{array}{l}\text { Mud, sand, rocks, } \\
\text { barnacles }\end{array}$ & Epi/Epl/Ez \\
\hline NR31. & & $\begin{array}{l}\text { Hydropuntia edulis (S.G. Gmelin) P.C. } \\
\text { Silva }\end{array}$ & + & & $\begin{array}{l}\text { Mud, rocks, } \\
\text { barnacles }\end{array}$ & Epi/Epl/Ez \\
\hline 32. & Rhodomelaceae & $\begin{array}{l}\text { Acanthophora spicifera (Vahl) } \\
\text { Borgesen }\end{array}$ & + & + & $\begin{array}{l}\text { Barnacles, rocks, } \\
\text { mud, sand }\end{array}$ & Ez/Epl/Epi \\
\hline 33. & & Laurencia cartilaginea Yamada & + & + & Mud, sand, rocks & Epi/Epl \\
\hline 34. & & $\begin{array}{l}\text { Laurencia papillosa (C. Agardh) } \\
\text { Greville }\end{array}$ & + & + & $\begin{array}{l}\text { Barnacles, mud, } \\
\text { sand, rocks }\end{array}$ & Ez/Epi/Epl \\
\hline 35. & & Laurencia perforata Montagne & + & & $\begin{array}{l}\text { Barnacles, mud, } \\
\text { rocks }\end{array}$ & Ez/Epi/Epl \\
\hline 36. & & $\begin{array}{l}\text { Leveillea jungermannioides (Hering et } \\
\text { Martens) Harvey* }\end{array}$ & + & & Seaweed & Epp \\
\hline NR37. & Rhodymeniaceae & $\begin{array}{l}\text { Gelidiopsis intricata (C. Agardh) } \\
\text { Vickers }{ }^{*}\end{array}$ & + & & Rocks & Epl \\
\hline
\end{tabular}

* Outside quadrat; + - present; Life forms: Epl-epilithic, Epp-epiphytic, Ez-epizoic, Epi-epipelic, NR-new record 
the macroalgae (Table 2) inhabiting the rocky area are those that require hard substrata for attachment. The rocky area with the availability of stable substrate and microhabitats provides favourable condition for the occurrence and diversity of macroalgae species (Chapman and Chapman, 1973). The sandy area lacks hard structure (Fig. 2) which is one of the reasons responsible for the relatively low diversity of macroalgae. The macroalgal species e.g. Caulerpa racemosa var. peltata and Ulva intestinalis attached to sandy substrate (nonepiphytic), as they possess rhizomaceous mode of growth enabling them to expand in the environment by vegetative means. In addition Ulva intestinalis is the dominant species at the rocky-sandy area due to its rapid growth and $t$ can withstand several hours of exposure to air during low tides. Studies by McConnaughey (1978) and Lobban et al., (1985) and muddy and sandy areas attribute fewer macroalgae, since most species cannot anchor as they regime to attach to some fixed and firm structure such as a rock, a shell or even another marine plant (Teo and Wee, 1983).

\section{Life forms}

The present study noted that various types of substrata were colonized by macroalgae from sand, rocks, animals such as snails, barnacles and other macroalgae. The availability of substratum obviously determined the diverse species composition of macroalgae (Norton et al., 1981). Based on mode of attachment on substrate types, macroalgae life form categories are epilithic, epipelic, epizoic and epiphytic. Epilithic macroalgae represents a big group (40-45.31\%). Epipeli (cor rhizophytic, $31.25-40 \%)$, epizoic (14.06-20.0\%) and epiphytic (0-9.38\%). The epilithic categories are present in the three divisions of Chlorophyta, Phaeophyta and Rhodophyta (Table 2). Copejans et al., (1992) reported at Gazi Bay, Kenya where they are most of the macroalgae were epilithic attached to the hard substrate such as rocks and corals. The high percentage representation in the epilithic macroalgae at Tg. Batu Kudu - Tg. Lubok Padok of the Similajau National Park reflects the availability of range of substrates (Japar Sidik et al., 1996; Brouns and Heijs, 1991). Based on the morphological conformation and macroalgae adaptation in order to attach to the substrates. Several macroalgae species; Ulva clathrata,
Sargassum polycystum, Gelidiella acerosa, Laurencia papillosa, L. perforata, and $L$. cartilaginea can exist as epilithic and epizoic since they were found attached on rocks as well as invertebrates such as barnacles, oysters and snails (Teo and Wee, 1983; Trono Jr., 1968). Macroalgae can also attached to the shells of live bivalve, Perna sp. (Muta Harah et al., 2006) and mollusc shells or polychaete tubes (Japar Sidik et al., 1996). Macroalgae with rhizoid can utilize marine plants as substrates (Japar Sidik et al., 1996). Epiphytic macroalgae were the least among the other life forms (Table 2).

In general, macroalgae species are able to settle and inhabit the marine environment. This is largely due to their ability to colonize mode of attachment to variety substrates such as rocks, sand, invertebrates and on other macroalgae. Although not observed in this study, nonetheless, there are a group of macroalgae under the category as drift macroalgae which does not attached to any substrates but remain free and still can survive in the environment (Chapman, 1979).

Acknowledgements. We would like to thank ViceChancellor, Universiti Putra Malaysia, for encouragement and facilities. This research is funded by the Ministry of Science, Technology and Environment Malaysia, under the 'Intensification of Research in Priority Areas' programme entitled "Distribution, diversity and uses of aquatic macrophytes" and, some financial and travel supports from Japan Society for the Promotion of Science (JSPS) are acknowledged.

\section{REFERENCES}

Brouns, J.J.W. and F.M.L. Heijs. 1991. Seagrass ecosystems in the tropical West Pasific. In: Mathieson, A.C. and P.H. Nienhuis. (eds.): Ecosystems of the World 24. Intertidal and Littoral Ecosystems. London, New York, Elsevier: 371-388.

Chapman, A.R.O. 1979. Biology of seaweeds: Levels of organization. USA, University Park Press. 134 p.

Chapman, V.J. and D.J. Chapman. 1973. The algae. $2^{\text {nd }}$ Edition. London, Macmillan. 497p.

Copejans, E., H. Beeckman and M.D. Wit. 1992. The seagrass and associated macroalgal vegetation of Gazi Bay (Kenya). In: Jaccarini, V. and E. Marten Kluwer. (eds.): Hydrobiologia. The ecology of 
mangrove and related ecosystems. Belgium, Academic Publisher: 59-75.

Fisheries Research Centre Sarawak. 2000. Seaweed resource of Sarawak. http://www.fri.gov.my/ friswak/eseaweed.htm.

Japar Sidik, B., A. Arshad, O. Hishamuddin, Z. Muta Harah and S. Misni. 1996. Seagrass and macroalgal communities of Sungai Pulai Estuary, South-West Johore, Peninsular Malaysia. In: Kuo, J., D.I. Walker and H. Kirkman (eds.): Seagrass Biology: Scientific Discussion from an International Workshop. Rottnest Island, Western Australia: 3-12.

Khew, K.L. 1978. Marine algae. In: Chua, T.E. and J.A. Mathias (eds): Coastal resources of West Sabah: An investigation into the impact of oil spill. Universiti Sains Malaysia, Pulau Pinang: 109-115.

Lobban, C.S., P.J. Harrison and M.J. Duncan. 1985. The physiological ecology of seaweeds. Cambridge University Press, USA. 242p.

McConnaughey, B.H. 1978. Introduction to marine biology. $3^{\text {rd }}$ Edition. C.V. USA, Mosby Company. $624 \mathrm{p}$.
Muta Harah, Z., B. Japar Sidik., A. Raesah, A. Suzalina Akma and O. Hisao. 2006. Marine macrophytes: Macroalgae species and life forms from Golden Beach, Similajau National Park, Bintulu, Sarawak, Malaysia. Coastal Marine Science 30(1): 243-246.

Norton, T.A., A.C. Matbieson and M. Neushul. 1981. Morphology and environment. In: Lobban C.S. and M.J. Wynne (eds.): The biology of seaweeds, Australia, Blackwell Scientific Publications: 421433.

Pole, R.W. 1974. An introduction to quantitative ecology. New York, Mc-Graw Hill Book Co. 426 p.

Saito, Y. and S. Atobe. 1970. Phytosociological study of intertidal marine algae I. Usujiri Benten-Jima, Hokkaido. Bulletin of Faculty of Fisheries, Hokkaido University 21(2): 37-69.

Teo, L.W. and Y.C. Wee. 1983. Seaweeds of Singapore. National University of Singapore, Singapore University Press. 123 p.

Trono Jr. G.C., 1968. The marine benthic algae of the Caroline Island, I: Introduction, Chlorophyta. Micronesica 4(2): 137-206. 